\title{
The right to justice: A challenge for survivors of conflict-related sexual violence in the Eastern Democratic Republic of the Congo
}

\section{Shirambere Philippe Tunamsifu*}

Research Assistant, Institute for Dispute Resolution in Africa, College of Law, University of South Africa; Lecturer in law, Université Libre des Pays des Grands Lacs, Democratic Republic of Congo

\begin{abstract}
Summary
In the eastern Democratic Republic of the Congo, since 1996 conflictrelated sexual violence against women and girls, particularly, has been a sad reality, even though these crimes are prohibited by international humanitarian law and criminalised by international and domestic criminal laws. When these violations occur, the perpetrators should be brought to justice. However, survivors face many challenges in holding perpetrators accountable, such as fear of speaking out due to cultural prohibitions, stigmatisation and fear of reprisals and rejection. The judiciary also faces challenges, including an insufficient budget, the lack of a competent court of law to deal with crimes of sexual violence in rural areas, poor equipment and a lack of education on crimes of sexual violence. In order to improve this situation, this research article argues that it is vital that the Congolese government establish competent courts of law to deal with crimes of sexual violence in rural areas and to ensure that officers of the judicial police are well trained, well remunerated and equipped to conduct investigations. Survivors should be adequately informed, encouraged and made aware of the fact that breaking the silence is an effective way of eradicating rape and other forms of sexual violence. Local communities should also be made aware and sensitised so that they do not reject survivors because unknown people have abused them.
\end{abstract}

Key words: Sexual violence; crimes; armed conflict; access to justice; Democratic Republic of the Congo

* MA (University for Peace), Hons (Licence) (Université Libre des Pays des Grands Lacs); tusphil@yahoo.fr 


\section{Introduction}

For almost two decades, the eastern part of the Democratic Republic of the Congo (DRC) has experienced an alarming number of ongoing non-international ${ }^{1}$ and internationalised armed conflicts. ${ }^{2}$ Domestic ${ }^{3}$ and foreign ${ }^{4}$ armed groups, as well as foreign armies, ${ }^{5}$ are involved in these armed conflicts. On the one hand, civilians are often the potential victims of indiscriminate attacks or the primary targets of violence because they cannot defend themselves. On the other, 'because civilians are not seen as a distinct group separate from enemy combatants, it is often difficult to deal with them separately'. ${ }^{6}$ In this regard, during different stages of these armed conflicts, all actors, including the armed forces of the DRC, or Forces Armées de la République Démocratique du Congo (FARDC), are alleged to have committed gross violations of human rights and serious violations of

1 According to art 1 of the Additional Protocol II, non-international armed conflicts are all armed conflicts which take place in the territory of a high contracting party between its armed forces and dissident armed forces or other organised armed groups fighting each other. See Protocol Additional to the Geneva Conventions of 12 August 1949, and relating to the protection of victims of non-international armed conflicts (Protocol II). In this case, the regular army was fighting against rebel groups such as Rassemblement Congolais pour la Démocratie (RCD), Mouvement pour la Libération du Congo (MLC) and Congrès National pour la Défense du Peuple (CNDP), but those armed groups were also facing resistance by other domestic small armed groups of May-May that wanted to protect their territories against occupation.

2 'The term "internationalised armed conflict" describes internal hostilities that are rendered international.' The circumstances that can achieve this are numerous and often complex: The term includes war between two internal factions, both of which are backed by different states; direct hostilities between two foreign states that militarily intervene in an internal armed conflict in support of opposing sides; and war involving a foreign intervention in support of an insurgent group fighting against an established government. See JG Steward 'Towards a single definition of armed conflict in international humanitarian law: A critique of internationalised armed conflict' (2003) 85 International Review of the Red Cross 315, citing D Schindler 'International humanitarian law and internationalised internal armed conflicts' (1982) IRRC 255. In this case, internationalised armed conflicts occurred when foreign states such as Rwanda and Uganda supported domestic armed groups against the government of the DRC.

3 The DRC has experienced and is still experiencing activity by various armed groups/militias. Examples are the Alliance des Forces Démocratiques pour Libération du Congo-Zaire (AFDL); the RCD; the MLC; the Union des Patriotes Congolais (UPC); the CNDP, the Patriotes Résistants Congolais/Forces Armées Populaires (PARECO/FAP); and the Mouvement du 23 Mars (M23), to cite only a few.

4 The Ugandan Allied Democratic Forces/National Army for the Liberation of Uganda (ADF/NALU), the Lord's Resistance Army (LRA) and the Forces Démocratiques pour la Liberation du Rwanda (FDLR) are among foreign armed groups terrorising civilian populations in the eastern DRC.

5 Foreign armies include the Rwandan Defence Force (RDF) and the Uganda People's Defence Force (UPDF).

$6 \mathrm{~T}$ Elbert et al Sexual and gender-based violence in the Kivu provinces of the Democratic Republic of Congo: Insights from former combatants (2013) 37. 
international humanitarian law. ${ }^{7}$ Of these, mass rape and other forms of sexual violence against girls and women, and sometimes men and boys, are the most cruel, causing enormous pain and affecting victims and the community as a whole directly and indirectly. However, there are few reports or literature on men and boys who have been raped (or even exposed to sexual violence) ${ }^{8}$ in eastern DRC because of a lack of disclosure due to shame and stigmatisation. The article therefore focuses on girls and women in the context of armed conflict.

Girls and women in the front line and in areas controlled or occupied by armed groups are particularly vulnerable. In 2008, MajorGeneral Patrick Cammaert, the then Deputy Force Commander of the UN Mission in the DRC, declared that 'it is now more dangerous to be a woman than to be a soldier in modern wars'. ${ }^{9}$ It is in this context that the article analyses sexual and gender-based violence as part of conflict-related sexual violence (CRSV) in the North Kivu province.

Indeed, prohibited by international humanitarian law, CRSV is criminalised by international and domestic criminal laws. When such violations occur, the perpetrators must be brought to justice. The article analyses the many challenges faced by survivors when attempting to hold perpetrators accountable.

The article first analyses the prevalence of CRSV globally and in the DRC. It explores the legal instruments prohibiting CRSV in armed conflicts. Second, it analyses the challenges faced by survivors in accessing justice and those faced by the judiciary in rendering justice. Third, it proposes a way forward.

$7 \quad$ M Nest et al The Democratic Republic of Congo: Economic dimensions of war and peace (2006) 12; A Binder et al Democratic Republic of the Congo (2010) 22; OHCHR Report of the mapping exercise documenting the most serious violations of human rights and international humanitarian law committed within the territory of the Democratic Republic of the Congo between March 1993 and June 2003 (2010) paras 998-999; PT Shirambere Culture of peace: Good governance in the Democratic Republic of the Congo (2014) 7217.

8 However, in their research project Johnson et al indicate that men and boys are also exposed to sexual violence. Thus, in a random sample, an exceptional study conducted found that $74,3 \%$ of women and $64,5 \%$ of men were exposed to conflict-associated sexual violence. Rape was reported as being the most common type of sexual violence, affecting $51,1 \%$ of women and $20,8 \%$ of men. See $\mathrm{K}$ Johnson et al Association of sexual violence and human rights violations with physical and mental health in territories of the Eastern Democratic Republic of the Congo (2010) 558 http://www.lawryresearch.com/553.full.pdf (accessed 6 October 2014).

9 S Chemaly 'Worldwide, it's "more dangerous to be a woman than a soldier in modern wars"' (2012) http://www.huffingtonpost.com/soraya-chemaly/rape-inconflict_b_1501458.html (accessed 6 October 2014). 


\section{Prevalence of conflict-related sexual violence globally and in the DRC}

\subsection{Conflict-related sexual violence globally}

In a situation of armed conflict, rape and other forms of sexual violence remain the predominant abuse perpetrated both by state actors (security forces) and non-state actors (rebel groups). In this regard, Rehn and Sirleaf argue as follows: ${ }^{10}$

Violence against women during conflict has reached epidemic proportions. Civilians have become the primary targets of groups who use terror as a tactic of war. Men and boys as well as women and girls are the victims of this targeting, but women, much more than men, suffer gender-based violence. Their bodies become a battleground over which opposing forces struggle. Women are raped as a way to humiliate the men they are related to, who are often forced to watch the assault.

In the same vein, Vlahoud and Biason reveal that ${ }^{11}$

[s] exual violence may be part of a calculated policy to attack the heart of a society, to demoralise and dishonour the opponent. The manner of the sexual violence is often such as to maximise the humiliation of the victim and their family and community and to ensure a level of powerlessness and fear that will remain entrenched.

Concerned about these atrocities in situations of armed conflict, the United Nations (UN) Secretary-General, in his report to the UN Security Council, uses the term 'conflict-related sexual violence' (CRSV). Indeed, as defined in his report of March 2015, the term CRSV refers to ${ }^{12}$

rape, sexual slavery, forced prostitution, forced pregnancy, enforced sterilisation and other forms of sexual violence of comparable gravity perpetrated against women, men, girls or boys that is linked, directly or indirectly (temporally, geographically or causally) to a conflict. This link may be evident in the profile of the perpetrator; the profile of the victim; in a climate of impunity or state collapse; in the cross-border dimensions; and/or in violations of the terms of a ceasefire agreement.

Indeed, during the 1994 genocide ${ }^{13}$ in Rwanda, between 250000 and 500000 women and girls were raped, and during the 1990 war

10 E Rehn \& EJ Sirleaf Women, war and peace: The independent experts' assessment on the impact of armed conflict on women and women's role in peace-building (2002) 10.

$11 \mathrm{M}$ Vlahoud \& L Biason Women in an insecure world: Violence against women facts, figures and analysis (2005) $14 \mathrm{http}: / / \mathrm{www}$.unicef.org/emerg/files/women insecure_world.pdf (accessed 17 October 2014).

12 UNSC Conflict-related sexual violence: Report of the Secretary-General, 23 March 2015, S/2015/203 para 2 http://www.securitycouncilreport.org/atf/cf/\%7B 65BFCF9B-6D27-4E9C-8CD3-CF6E4FF96FF9\%7D/s_2015_203.pdf (accessed 4 September 2015).

13 Rehn \& Sirleaf (n 11 above) 9. 
in Bosnia and Herzegovina, between 20000 and 50000 women were raped. ${ }^{14}$ Survivors of CRSV are often rejected or abandoned by their husbands or partners and families and shunned by their communities. ${ }^{15}$ Turshen states that rape causes lifelong physical and psychological suffering to victims and destroys families and larger social networks as well as individual economic capacity. ${ }^{16}$ Besides, rape also tends to spread sexually-transmitted infections (STIs), including HIV, ${ }^{17}$ and victims experience unplanned and unwanted pregnancies. On 25 November 2006 Kofi Annan, the then UN Secretary-General, observed: ${ }^{18}$

Violence against women causes untold misery, harms families across generations, and impoverishes communities. It stops women from fulfilling their potential, restricts economic growth, and undermines development. When it comes to violence against women there are no civilised societies.

When assessing the situation, the UN Secretary-General, Ban Ki-moon, noted that ${ }^{19}$

[a]Il too often, perpetrators go unpunished. Women and girls are afraid to speak out because of a culture of impunity. We must fight the sense of fear and shame that punishes victims who have already endured crime and now face stigma. It is the perpetrators who should feel disgraced, not their victims.

In December 1999, the UN Secretary-General stated his concern that violence against women and girls, inflicted by men, was widespread throughout the globe in developing and developed countries, affecting women, no matter what their race, ethnicity, social origin, property, birth or other status. On International Women's Day, Kofi Annan observed that violence against women was the most shameful human rights violation that must be recognised and condemned. ${ }^{20}$ In this regard, following the Declaration on the Elimination of Violence

14 J Ward If not now, when? Addressing gender-based violence in refugee, internallydisplaced, and post-conflict settings: A global overview (2002) 81 http://www. rhrc.org/resources/ifnotnow.pdf (accessed 17 October 2014).

15 L Hovil Gender, transitional justice, and displacement: Challenges in Africa's Great Lakes region (2012) 6.

16 Turshin, cited by Elbert et al ( $\mathrm{n} 6$ above) 7.

17 Former CNDP combatants admitted that violence against women was practised by their group to spread AIDS in the victims' communities. See Elbert et al (n 6 above) 51 .

18 K Annan 'International Day for the Elimination of Violence against Women on 25 November' (2006) http://www.un.org/News/Press/docs/2006/sgsm10738. doc.htm (accessed 4 October 2014).

19 B Ki-moon 'International Day for the Elimination of Violence against Women 25 November' (2012) http://www.un.org/en/events/endviolenceday/2012/sgmes sage.shtml (accessed 4 October 2014).

20 K Annan 'Violence against women "most Shameful", pervasive human rights violation' http://www.un.org/press/en/1999/19990308.sgsm6919.html (accessed 11 November 2015). See also B Ki-moon 'Message for the International Day for the Elimination of Violence against Women, 25 November' (2011) http:// www.un.org/News/Press/docs/2011/sgsm13955.doc.htm (accessed 4 October 2014). 
against Women, ${ }^{21}$ the UN General Assembly adopted Resolution 54/ 134, designating 25 November as the International Day for the Elimination of Violence against Women. ${ }^{22}$ Nevertheless, violence against women and girls around the world did not cease or decrease. On 25 November 2012 Ban Ki-moon acknowledged that ${ }^{23}$

[m]illions of women and girls around the world are assaulted, beaten, raped, mutilated or even murdered in what constitutes appalling violations of their human rights. From battlefield to home, on the streets, at school, in the workplace or in their community, up to 70 per cent of women experience physical or sexual violence at some point in their lifetime.

\subsection{Conflict-related sexual violence in the DRC}

Since 1996, when the first internationalised armed conflict started in the eastern DRC, rape and other forms of sexual violence against women and girls, in particular, have become a sad reality of war. National and foreign soldiers and members of armed groups involved are alleged to have committed violence, accompanied by the systematic use of rape and sexual assault. ${ }^{24}$ Statistics often help to illustrate the pervasive use of CRSV in the North Kivu province, even though many cases go unreported. Cases of sexual violence over the last ten years are presented in Table 1.

Table 1: Incidents of sexual gender-based violence in North Kivu between 2004 and 2013

\begin{tabular}{|l|l|l|}
\hline No & Year & Cases of sexual violence \\
\hline 01 & 2004 & 5527 \\
\hline 02 & 2005 & 5190 \\
\hline 03 & 2006 & 4238 \\
\hline 04 & 2007 & 3063 \\
\hline 05 & 2008 & 4820 \\
\hline 06 & 2009 & 4026 \\
\hline 07 & 2010 & 54885 \\
\hline 08 & 2011 & 6898 \\
\hline
\end{tabular}

21 UNGA Resolution 48/104 (1994).

22 UNGA Resolution 54/134 (1999) http://www.un.org/en/ga/search/view doc.asp?symbol= A/RES/54/134 (accessed 6 October 2014).

$23 \mathrm{Ki}$-moon (n 19 above).

24 OHCHR (n 8 above) para 35; Elbert et al (n 6 above) 19294346 57-59. 


\begin{tabular}{|l|l|l|}
\hline 09 & 2012 & 7075 \\
\hline 10 & 2013 & 3177 (first semester only) \\
\hline
\end{tabular}
Sources: Cases of sexual violence from 2004 to $2009 ;{ }^{25}$ cases of sexual violence in
$2010 ; 26$ cases of sexual violence in 2011,27 cases of sexual violence in 2012; cases of sexual violence in 2013 (first semester) ${ }^{29}$

A number of authors have met soldiers and combatants who revealed several incidents of rape and sexual violence during armed conflict. According to the study by Elbert et al, poverty may explain why Congolese soldiers rape women. Due to their low salaries, soldiers are often unable to convince women to have consensual sex or to pay for it; they also have poor living conditions that cause their wives to love them less than they feel they deserve. The resulting frustration causes them to commit such harmful acts, 30 whereas the mission of the FADRC is to defend the integrity of the national territory and borders. ${ }^{31}$ Unfortunately, tolerance and a lack of punishment at leadership level seems to have encouraged such misconduct. ${ }^{32}$ This may be why Congolese soldiers are often prosecuted when the DRC is under international pressure, ${ }^{33}$ but

25 NGOs Présentation des cas incidents des violences sexuelles au Nord Kivu rapportés par les Commissions Territoriales de Lutte contre les Violences Sexuelles (CTLVS). Période couverte: Janvier à Décembre 2009. Data collected at the office of the local NGO Dynamique de Femmes Juristes (DFJ), Goma, on 10 January 2015.

26 UNFPA Cas incidents de violences sexuelles enregistrés en 2010 au Nord Kivu. Data collected at the office of the local NGO Dynamique de Femmes Juristes (DFJ), Goma, on 10 January 2015.

27 Indicateurs des violences sexuelles et basées sur le genre des territoires de la Province du Nord Kivu. Data collected at the office of the local NGO DFJ, Goma, on 10 January 2015.

28 Division du genre, famille et enfant du Nord Kivu en RDC. Présentation des données SGBV au Nord Kivu/ 2012. Data collected at the office of the local NGO DFl, Goma, on 10 January 2015.

29 UNFPA, Réunion de validation des données des VSBG collectées au 1er Semestre 2013 dans la Province du Nord-Kivu. Data collected at the office of the local NGO DFJ, Goma, on 10 January 2015.

$30 \quad$ Elbert et al ( $\mathrm{n} 6$ above) 19.

31 See art 187 of the Constitution, which provides (in French): 'Les Forces armées ... ont pour mission de défendre l'intégrité du territoire national et les frontières.'

32 Human Rights Watch Les soldats violent, les commandants ferment les yeux: Violences sexuelles et réforme militaire en République Démocratique du Congo (2009) 5.

33 During 2013, 61 members of the national defence and security forces were sentenced for crimes of sexual violence, including four members of the national police force, 33 FARDC members and 24 other state agents. In addition, in the Minova case, the operational military court of North Kivu province prosecuted 40 FARDC members, including five high-ranking officers alleged to have raped women in and around Minova between 20 November and 4 December 2012. However, rebels who fled into Rwanda and Uganda have not yet been tried. See Report of the Secretary-General to the UNSC on conflict-related sexual violence of 13 March 2014 S/2014/181, http://www.securitycouncilreport.org/atf/cf/\%7B65B FCF9B-6D27-4E9C-8CD3-CF6E4FF96FF9\%7D/s_2014_181.pdf (accessed 26 January 2015). 
members of the rebel forces have not yet been prosecuted. Elbert et al interrogated national and foreign combatants such as those belonging to PARECO, CNDP and FDLR. While Congolese soldiers do not seem to have been given instructions, other combatants were given orders to rape women and girls. According to participants in the study, ${ }^{34}$

[a]lmost one-third of former CNDP combatants affirmed that such orders were given. Furthermore, 14 per cent of former PARECO combatants and 16 per cent of former FDLR combatants reported orders to rape civilians.

However, despite media campaigns against rape and all forms of sexual violence against women and girls, without particular orders, some soldiers and combatants lost all discipline and raped women and girls under the influence of traditional local drugs and marijuana. Elbert et al argue that this can be seen as an excuse because 'in court trials, the defendant would not be considered as fully responsible if he were intoxicated with substances at the time of a committed crime' ${ }^{35}$

Women give birth and through marriage unite families, communities and nations. In the Congolese tradition, they are traditionally and generally respected and, therefore, subjected to protection because they are the 'glue' that unites communities. In this regard, the humiliation of women becomes the communities' humiliation and women are destroyed because communities are destroyed. In other words, there are probably other ways to destroy a community but, unfortunately, an effective way is to destroy its women. Thus, CRSV goes beyond affecting women as human beings; it can be seen as violence against the community as a whole. In other words, it may be assumed that many goals are achieved when the leaders of armed groups order their combatants to perpetrate rape and other forms of sexual violence. Indeed, Elbert et al found that if women living in the territory controlled by an armed group are suspected of collaborating with the enemy, brutal forms of rape are used as a punishment, ${ }^{36}$ humiliation, or to gain political attention.

In armed conflict, non-combatant women are part of the civilian population that should be protected; they are unarmed and therefore cannot defend themselves. The national army has a duty to secure its territory and to protect its civilian population. When the army is unable to do so, the vulnerability of women is exploited to weaken its morale; the opposing armed group may organise sporadic attacks on the territory controlled by the government and may rape women. This behaviour is seen as a defeat for the national army and, therefore, a victory for the armed group that perpetrated the raid. ${ }^{37}$ In addition, women are also considered a 'precious resource'; as such, the ability to protect them demonstrates the strength of the national army.

34 Elbert et al ( $\mathrm{n} 6$ above) 43.

35 Elbert et al 30-31.

36 Elbert et al 57.

37 Elbert et al 58. 
Thus, combatants invade the territory and rape women to 'demonstrate the group's superiority' ${ }^{38}$ vis-à-vis the national army. An illustration is the M23 rebels' occupation of the town of Goma on 20 November 2012. The first thing they did inside the military camp of Katindo was to rape the wives of FARDC soldiers who had fled during their advance. ${ }^{39}$ It is in this regard that Elbert et al find that 'women are not seen as independent agents or carriers of rights and dignity'. 40

Clearly, there are also tactical and strategic aspects of sexual violence in the Eastern DRC. SGBV may be employed to demonstrate a group's strength and to draw political/public attention to it, or to terrorise civilians into compliance with the armed group's rules. When looking at strategic motives, it is assumed that armed groups perpetrating SGBV intend overall political gain. From a tactical perspective, it is assumed that SGBV is perpetrated to achieve immediate objectives in a particular engagement. The research found evidence of underlying strategic (for example, to gain political attention), tactical (for example, to facilitate lootings), as well as of overlapping strategic and tactical (for example, to control civilians) aspects of SGBV in DRC. ${ }^{4}$

Considering the above, the author agrees with Aristotle, that ' $[f]$ or man, when perfected, is the best of animals; but, when separated from law and justice, he is the worst of all'. ${ }^{2}$ 'The next section explores the laws prohibiting CRSV in armed conflict.

\section{Legal instruments preventing and prohibiting conflict-related sexual violence}

The law of armed conflict or international humanitarian law legally binds all parties (states and armed groups) and applies in both international and non-international armed conflicts. For instance, Common Article 3 to the Geneva Convention of 1949 is applied to and binds each party to armed conflict not of an international character. In addition, article 96(3)(c) of Protocol 1 of 1977 to the Geneva Convention of 1949 stipulates that 'the Conventions and this Protocol are equally binding upon all parties to the conflict'. Thus, contrary to the general principle of pacta sunt servanda in

$38 \quad$ Elbert et al 59.

39 See Report of the United Nations Joint Human Rights Office (UNJHRO) on human rights violations committed by the Mouvement du 23 Mars (M23) in North Kivu province between April 2012 and November 2013 in the Democratic Republic of the Congo, October 20148 http://www.ohchr.org/Documents/Countries/CD/ UNJHROOctober2014_en.pdf (accessed 20 October 2014).

40 Elbert et al ( $\mathrm{n} 6$ above) 59.

41 Elbert et al 60.

42 Aristotle http://buf.no/pdf/ipo2010-paulkuse.pdf (accessed 14 October 2014). 
international law, ${ }^{43}$ non-state armed groups 'are bound as a matter of international customary law to observe the obligations declared by Common Article 3 which is aimed at the protection of humanity'. ${ }^{44}$ However, two criteria need to be satisfied by armed non-state actors for the application of international humanitarian law. The first is 'the criterion of protracted armed violence as ... referring to the intensity of the armed violence rather than to its duration', ${ }^{45}$ and the second is the 'organisation' criterion to confront each other with military means. ${ }^{46}$ The international humanitarian law is 47

a set of rules which seek for humanitarian reasons to limit the effects of armed conflict. International humanitarian law protects persons who are not or who are no longer participating in hostilities and it restricts means and methods of warfare.

The four Geneva Conventions of 1949 and the two additional protocols of $1977^{48}$ constitute a major part of international humanitarian law. Thus, they provide legal protection to people who are not or are no longer participating directly in hostilities. Article 13(1) of Additional Protocol II stipulates that '[t]he civilian population and individual civilians shall enjoy general protection against the dangers arising from military operations'. Article 27 of the Fourth Geneva Convention of 1949 relating to the Protection of Civilian Persons in Time of War provides that '[w]omen shall be especially protected against any attack on their honour, in particular against rape, enforced prostitution, or any form of indecent assault'. Therefore, the UN Security Council, through Resolution 1325 $(2000),{ }^{49}$

[c]alls on all parties to armed conflict to take special measures to protect women and girls from gender-based violence, particularly rape and other forms of sexual abuse, and all other forms of violence in situations of armed conflict.

43 The principle pacta sunt servanda is provided for by art 26 of the Vienna Convention on the Law of Treaties (1969). The provision stipulates that '[e]very treaty in force is binding upon the parties to it and must be performed by them in good faith'.

44 Special Court for Sierra Leone, Appeals Chamber 'Decision on Challenge to Jurisdiction: Lomé Accord Amnesty' Prosecutor against Morris Kallon (Case SCSL2004-15-AR72(E) and Brima Bazzy Kamara (Case SCSL-2004-16-AR72(E), para 47 13 March 2004 http://www.rscsl.org/Documents/Decisions/AFRC/Appeal/033/ SCSL-04-16-PT-033.pdf (accessed 12 November 2015).

45 International Criminal Tribunal for the Former Yugoslavia, Prosecutor $v$ Ramush Haradinaj Case IT-04-84-T, para 49, 3 April 2008 http://www.icty.org/x/cases/ haradinaj/tjug/en/080403.pdf (accessed 12 November 2015).

46 Prosecutor $v$ Ramush Haradinaj (n 45 above) para 60.

47 International Committee of the Red Cross (ICRC) The domestic implementation of international humanitarian law: A manual (2013) 13.

48 There are two Additional Protocols I and II of 1977, relating to the protection of victims of armed conflicts, and the third of 2005 (Additional Protocol III) relates to the adoption of an additional distinctive emblem.

49 UNSC Resolution 1325 (2000) http://www.un.org/en/ga/search/view_doc.asp? symbol=S/RES/1325\%282000\%29 (accessed 4 October 2014). 
Indeed, from 1950 to 2000, 194 states ratified the Geneva Conventions of 1949 and Additional Protocols. ${ }^{50}$ Therefore, these conventions are the most widely-accepted legal instruments. Like the rule of customary law, most of their provisions are considered as a norm of jus cogens that creates obligations erga omnes binding on all states without exception. These fundamental humanitarian principles 'developed as a result of centuries of warfare and had already become customary law at the time of the adoption of the Geneva Conventions because they reflect the most universally recognised humanitarian principles ${ }^{51}$ and the most highly-ratified treaties in the world. In this regard, they have gained greater authority and their impact on public international law is difficult to overestimate. ${ }^{52}$ However, Nieto-Navia argues that ${ }^{53}$

[i]t is suggested that many of the provisions cannot truly be described as jus cogens ... only those principles underlying Common Article $3 \ldots$... can be identified as having reached the relevant standard.

Indeed, by ratifying and incorporating the Geneva Conventions of 1949 and Additional Protocols into domestic law, the contracting parties send a strong message that they are committed to abiding by and applying international humanitarian law in good faith: ${ }^{54}$

The ratification of international humanitarian law treaties creates the obligation for states to disseminate the rules and obligations they contain in order to have them respected by all parties to an armed conflict and to ensure a more humane conduct of armed conflict. In incorporating those conventions into domestic law, states have to provide for sanctions for serious breaches of their provisions.

In this regard, to ensure its commitment, the DRC ratified the Geneva Conventions of 1949 on 3 June 1982 and the Additional Protocol of 1977 on 12 December 2002. However, Additional Protocol III of 2005 relating to the adoption of an additional distinctive emblem has not yet been ratified by the DRC. The Convention on the Rights of the Child of 1989 (CRC) was ratified on 27 September 1990 and the

50 See Comité International de la Croix-Rouge (CICR) 'The Geneva Conventions of 1949 and their Additional Protocols' ${ }^{\prime}$ https://www.icrc.org/fre/war-and-law/ treaties-customary-law/geneva-conventions/overview-genevaconventions.htm\#header (accessed 17 November 2014).

51 ICTY The Prosecutor v Zejnil Delali_\& Others Judgment, Case IT-96-21-A para 143, 20 February $2001 \mathrm{http} / /$ www.icty.org/x/cases/mucic/acjug/en/cel-aj010220.pdf (accessed 13 November 2015).

52 The Geneva Conventions and Public International Law British Foreign and Commonwealth Office Conference commemorating the 60th anniversary of the 1949 Geneva Conventions, London, 9 July 2009 https://www.icrc.org/eng/assets/ files/other/irrc-875-geneva-convention-int-law.pdf (accessed 13 November 2015).

53 R Nieto-Navia 'International peremptory norms (jus cogens) and international humanitarian law' (2001) 27 http://www.iccnow.org/documents/Writing ColombiaEng.pdf (accessed 13 November 2015).

54 ICRC (n 47 above) 20. 
Optional Protocol on the involvement of children in armed conflict of 2000 was ratified on 11 November 2001.55 Thus, as mentioned earlier, the aims of the international humanitarian law treaties are to protect persons who are not or who are no longer taking part in hostilities and to minimise the effects of armed conflicts. ${ }^{56}$ Violations of international humanitarian law treaties constitute crimes under international law; nevertheless, no penal sanctions for persons alleged to have committed such crimes are provided. However, it is argued that a sanction or penalty is part of a coherent legal structure and the threat of punishment is a deterrent. Thus, international humanitarian law treaties impose an obligation on states to provide a system of criminal punishment in order to prosecute alleged perpetrators of serious offences, to seek to bring them before their own courts or to hand them over to another state for trial. ${ }^{57}$ Therefore, there is no excuse for state actors (security forces) and non-state armed groups to breach international humanitarian law treaties.

As defined in the Rome Statute of the International Criminal Court (ICC), international crimes have been incorporated in the Military Criminal Code of the DRC in the same words. In this regard, the crime of genocide is covered in article 164 and crimes against humanity in articles 165 to 172 . The death penalty is the sentence if a victim dies or if the acts cause serious harm to his or her body. Articles 173 to 175 of the Military Criminal Code provide for war crimes. ${ }^{58}$ Since

55 ICRC treaties and state parties to such treaties https://www.icrc.org/applic/ihl/ ihl.nsf/vwTreatiesByCountrySelected.xsp?xp_countrySelected=CD (accessed 22 October 2014).

56 J Kellenberger 'Foreword' in ICRC (n 47 above) 20.

57 Art 49 of the Geneva Convention I, art 50 of the Geneva Convention II, art 129 of the Geneva Convention III and art 146 of the Geneva Convention IV stipulate in the same manner that '[t]he High Contracting Parties undertake to enact any legislation necessary to provide effective penal sanctions for persons committing, or ordering to be committed, any of the grave breaches of the present Convention defined in the following article. Each High Contracting Party shall be under the obligation to search for persons alleged to have committed, or to have ordered to be committed, such grave breaches, and shall bring such persons, regardless of their nationality, before its own courts. It may also, if it prefers, and in accordance with the provisions of its own legislation, hand such persons over for trial to another High Contracting Party concerned, provided such High Contracting Party has made out a prima facie case. Each High Contracting Party shall take measures necessary for the suppression of all acts contrary to the provisions of the present Convention other than the grave breaches defined in the following article. In all circumstances, the accused persons shall benefit by safeguards of proper trial and defence, which shall not be less favourable than those provided by article 105 and those following the Geneva Convention relative to the Treatment of Prisoners of War of August 12, 1949.'

58 ST Shirambere 'International humanitarian law violations in the armed conflict in eastern part of DR Congo: The case of the National Congress for the Defence of People' (2012) 2 Journal of International Law 250. 
11 April 2013, both military and civil courts have had jurisdiction over international crimes. ${ }^{59}$

Indeed, regarding conflicts not of an international character, Common Article 3(1) to the Geneva Conventions and to the APII specifies:

In the case of armed conflict not of an international character occurring in the territory of one of the High Contracting Parties, each party to the conflict shall be bound to apply, as a minimum, the following provisions:

(1) Persons taking no active part in the hostilities, including members of armed forces who have laid down their arms and those placed hors de combat by sickness, wounds, detention, or any other cause, shall in all circumstances be treated humanely, without any adverse distinction founded on race, colour, religion or faith, sex, birth or wealth, or any other similar criteria.

To this end, the following acts are and shall remain prohibited at any time and in any place whatsoever with respect to the above-mentioned persons:

(a) violence to life and person, in particular murder of all kinds, mutilation, cruel treatment and torture;

(b) taking of hostages;

(c) outrages upon personal dignity, in particular humiliating and degrading treatment;

(d) the passing of sentences and the carrying out of executions without previous judgment pronounced by a regularly constituted court, affording all the judicial guarantees which are recognised as indispensable by civilised peoples.

The essence of this provision is to protect people who are not or who are no longer taking part in hostilities, whatever their gender. In this regard, article 3(1) of the Geneva Conventions and Additional Protocol II protects the human dignity of both men and women equally and does not consider the fact that women and girls are potential victims in conflict situations. However, if women are in prison, wounded or sick, international humanitarian law grants them specific treatment due to their sex, as favourable as that granted to men. ${ }^{60}$

As CRSV can be used to terrorise communities, article 13(2) of Additional Protocol II prohibits acts or threats of violence intended to spread terror among the civilian population. Article 12 of Geneva Convention I and Geneva Convention II, as well as article 14 of Geneva Convention III, provide that persons who are wounded, sick, shipwrecked or prisoners of war shall be treated humanely without any adverse distinction. These provisions state that women shall be

59 Previously, military criminal courts and tribunals had exclusive jurisdiction over international crimes as provided for in art 161 of the Military Code or Law 024/ 2002 of 18 November 2002. Under art 91 of the Organic Law 13/011-B of 11 April 2013, civil courts have jurisdiction to deal with international crimes (Loi organique $n^{\circ} 13 / 011-B$ du 11 avril 2013 portant organisation, fonctionnement et compétences des juridictions de l'ordre judiciaire).

60 See art 12 of the Geneva Convention of 1949 I \& II, and art 14 of the Geneva Convention III. 
treated with all consideration due to their gender. Here also, women and men enjoy equal protection, which varies according to the situations in which women find themselves. In this regard, article 76 of Additional Protocol I provides special measures to protect women and children. Paragraph 1 stipulates that ' $[\mathrm{w}]$ omen shall be the object of special respect and shall be protected in particular against rape, forced prostitution and any other form of indecent assault'. In the same vein, article 27(2) of Geneva Convention IV provides that women shall be especially protected against any attack on their honour, in particular against rape, forced prostitution, or any form of indecent assault. Article 75(2b) of Additional Protocol I states that outrages upon personal dignity, in particular humiliating and degrading treatment, forced prostitution and any form of indecent assault remain prohibited at any time and in any place whatsoever, whether committed by civilian or military agents. Further, article 4(2)(e) of Additional Protocol II outlines that outrages upon personal dignity, in particular humiliating and degrading treatment, rape, enforced prostitution and any form of indecent assault, remain prohibited at any time and in any place whatsoever.

There are customary international humanitarian law rules in addition to international humanitarian law treaties. ${ }^{61}$ Thus, according to Rule 93 of customary international humanitarian law relative to rape and other forms of sexual violence, state practice establishes the prohibition of rape and other forms of sexual violence as a norm of customary international law applicable in both international and noninternational armed conflicts. In addition, Rule 94 prohibits slavery and slave trade in all their forms, and state practice establishes this rule as a norm of customary international law applicable in both international and non-international armed conflicts. Rule 134 provides that the specific protection, health and assistance needs of women affected by armed conflict must be respected. The rule also prohibits sexual violence.

Rape is the violation of the right to physical integrity and the most common form of sexual violence committed in eastern DRC in violation of laws and customs of war. Rule 156 states that serious violations of international humanitarian law constitute war crimes. Thus, rape has been criminalised within different statutes of ad hoc international criminal courts and listed among crimes against humanity. This is the case in, for example, article 5(g)(i) of the Statute of the International Criminal Tribunal for the former Yugoslavia of $1993 i^{62}$ articles $3(\mathrm{~g})(\mathrm{i})$ and $4(\mathrm{e})$ of the Statute of the International

61 JM Henckaerts \& L Doswald-Beck Customary international humanitarian law Vol I: Rules (2009).

62 During the armed conflict between Bosnia Serbs and Bosnian Muslims in the area of Foča from April 1992 to February 1993, non-Serb civilians, especially Muslim women, were detained, killed and raped in violation of the laws and customs of war. Thus, three Bosnian Serb army officers, namely, Dragoljub Kunarac, Radomir Kovač and Zoran Vuković, were accused of torture, rape and enslavement. See 
Criminal Tribunal for Rwanda of $1994 ; ;^{63}$ and articles 2(f), (g) and (i) of the Statute of the Special Court for Sierra Leone of 2000. However, articles $8(2)(b)(x x i i)$ and $8(2)(e)(v i)$ of the Rome Statute of the ICC list rape as a war crime.

At the regional level, the Protocol to the African Charter on Human and Peoples' Rights on the Rights of Women in Africa (African Women's Protocol) encourages state parties to adopt and implement appropriate measures to ensure the protection of women from all forms of violence, particularly sexual and verbal violence (article 3(4)). In addition, article 4 stipulates that state parties shall take appropriate effective measures to enact and enforce laws to prohibit all forms of violence against women; take appropriate measures to prevent and eliminate such violence (c); punish the perpetrators (e); establish mechanisms for rehabilitation and reparation for victims ( $f$ ); and provide adequate budgetary and other resources to monitor actions aimed at preventing and eradicating violence against women (i).

In the Great Lakes region of Africa, sexual violence against women and children is among the issues that member states combat through the Protocol on the Prevention and Suppression of Sexual Violence against Women and Children (article 11). At the domestic level, the DRC has the duty to prevent acts of sexual violence and to prosecute and punish whoever is found guilty. Article 15 of the Constitution of the DRC of 2006, as revised in 2011, provides that any sexual violence committed against any person with the intention to destabilise or to displace a family and to make a whole people disappear is a crime against humanity. ${ }^{64}$ In addition, two laws on sexual violence were adopted in July 2006. The first defines and criminalises different acts

ICTY, The Prosecutor v D Kunarac, $R$ Kovač and Z Vukovič Case IT-96-23 \& IT-96-23/ 1-A, para 1-22 http://www.icty.org/x/cases/kunarac/acjug/en/kun-aj020612e.pdf (accessed 16 November 2015). In this regard, rape was used to implement a strategy of expulsion of the Muslims out of the region of Foča through terror. This was a way in which 'the Serbs could assert their superiority and victory over the Muslims'. See ICTY 'Kunarac et al. Sexual enslavement and rape as crimes against humanity' http://www.icty.org/en/in-focus/crimes-sexual-violence/landmark-cases (accessed 16 November 2015). Judiciously, the Trial Chamber found that the accused were guilty of crimes against humanity and, therefore, sentenced them respectively to 28, 20 and 12 years' imprisonment. The Appeals Chamber confirmed the sentences imposed on the appellants by the Trial Chamber. See ICTY The Prosecutor v D Kunarac, R Kovač and Z Vukovič Case IT-96-23 \& IT-96-23/ 1 -A, paras $10,18,22 \& 414$

63 The International Criminal Tribunal for Rwanda in the case of the Prosecutor $v$ JeanPaul Akayesu Case ICTR-96-4-T, the Chamber defines rape as physical invasion of a sexual nature, committed on a person under circumstances which are coercive (para 598). Thus, Jean-Paul Akayesu, judged criminally responsible under art 3(g) of the Statute, was found guilty of a crime against humanity (rape), http:// www.unictr.org/Portals/0/Case\%5CEnglish\%5CAkayesu\%5Cjudgement\%5Cakay 001. pdf (accessed 25 November 2010).

64 Translated from the original French: 'Les pouvoirs publics veillent à l'élimination des violences sexuelles. Sans préjudice des traités et accords internationaux, toute violence sexuelle faite sur toute personne, dans l'intention de déstabiliser, de disloquer une famille et de faire disparaître tout un peuple est érigée en crime contre l'humanité puni par la loi.' 
of sexual violence, ${ }^{65}$ and the second relates to criminal procedure, providing a maximum of three months for the duration of the judicial proceedings. ${ }^{66}$

\section{Challenges for survivors in accessing justice}

Before analysing the challenges that face survivors of sexual violence in gaining access to justice, this section analyses the guarantees of the right to justice.

\subsection{Right to justice}

The right to justice is guaranteed by a number of international and domestic instruments. These include the International Covenant on Civil and Political Rights of 1966 (article 2); the Convention against Torture and Other Cruel, Inhuman, Degrading Treatment or Punishment of 1984 (articles 4, 5, 7 and 12); and the International Convention for the Protection of All Persons from Enforced Disappearance of 2007 (articles 3, 6 and 11). At the domestic level, article 19 of the Constitution of the DRC of 2006, as revised in 2011, guarantees the right to justice. This right requires proper administration of justice, regardless of a person's gender.

However, in the aftermath of armed conflict, it is common for postconflict states to face challenges in rebuilding themselves. In the case of the DRC, as a result of various armed conflicts, some public institutions, including the judiciary and private infrastructures, were in poor condition. In this regard, assessing the state of the judiciary after conflicts, the UN Special Rapporteur on the Independence of Judges and Lawyers, Leandro Despouy, concluded that the judicial system was 'in a deplorable state' ${ }^{67}$ Often the judiciary in post-conflict countries lacks the financial resources to either rebuild itself or to prosecute crimes committed during the conflict. ${ }^{68}$ It is reported that '[w]hile most countries spend between $2 \%$ and $6 \%$ of their national budgets on justice, the DRC only spent an average of $0,6 \%$ per year between 2004 and $2009^{\prime} .{ }^{69}$ The budget of the Congolese judicial system remains insufficient to deal with crimes committed in conflict situations. Apart from this, judicial police officers and judges are not

65 Loi no 06/018 du 20 juillet 2006 modifiant et complétant le Décret du 30 janvier 1940 portant Code Pénal Congolais.

66 Loi no 06/019 du 20 juillet 2006 modifiant et complétant le Décret du 06 août 1959 portant Code de Procédure Pénale Congolais.

67 OHCHR (n 8 above) para 895.

68 In this regard, the report of the OHCHR provides that '[i]n many respects the incapability of the justice system in the DRC is a direct result of a lack of adequate financial resources'. See OHCHR (n 8 above) paras 900-901. 
yet adequately paid and this seriously affects their work. ${ }^{70}$ Another issue is that only major cities have complete tribunals and courts of law, which is not the case in rural areas. ${ }^{7}$

Judicial sector personnel, in the best of situations, are poorly paid, if at all, lack operational and professional capacity and adequate training, and justifiably refuse to work in isolated zones where their security and basic daily needs (including housing) cannot be assured. At the same time, they express a strong desire to increase their own capacities and find their current working conditions profoundly frustrating and at times degrading.

The next subsection focuses on the challenges faced by survivors in accessing justice and those faced by the judicial system in rendering justice in the DRC.

\subsection{Challenges to accessing justice}

Humanitarian workers, health carers and human rights defenders report that thousands of women and girls pay a particularly heavy price, which includes the systematic use of rape and sexual violence allegedly committed by government forces, rebels and civilians. ${ }^{72}$ The large scale of rape and other forms of sexual violence perpetrated against women and girls in North Kivu province occurred and continues in the rural areas where fighting between the Congolese army and the rebel movement occurs frequently. In these areas, as the author witnessed, local customs and cultures are followed by local communities.

Many aspects prevent access to justice for survivors: culture; stigmatisation; fear of being rejected by their partners or husbands; fear of being neglected by family members; fear of reprisals; fear of intimidation by the offender, especially if he is a member of the national army or the national police or of the occupying power (rebel group); lack of interest if the perpetrator is unknown, especially if he is a member of a foreign army or a foreign armed group; competent courts far away (geographical challenge); lack of training, professional development and specialisation among local police; lack of reparation; corruption within the judiciary; and impunity. ${ }^{73}$

70 In 2010, the UN Human Rights Office of the High Commissioner delivered a report in which magistrates expressed their concern about the poor levels of remuneration, arguing that the 'vast majority of Congolese magistrates consider that salaries received by them and other personnel in the Congolese justice system do not provide a decent living standard'. OHCHR (n 8 above) para 940. Although the salary has been improved from around $\$ 450$ to around $\$ 600$, it is still not sufficient.

71 E Brusset et al Joint evaluation of conflict prevention and peace building in DRC (2011) $83 \mathrm{http}: / / \mathrm{www}$.oecd.org/countries/congo/48859543.pdf (accessed 3 February 2015).

72 See OHCHR ( 8 above) para 35.

73 Amnesty International, Democratic Republic of Congo: Amnesty International submission to the UN Universal Periodic Review (2009) 5 http://www. amnesty.org/en/library/asset/AFR62/009/2009/en/536d63eb-4c71-4c19-bd19-c0 14966bb7cf/afr620092009en.pdf (accessed 9 February 2015). 
High levels of rape and other forms of sexual violence continue to be reported across the country, particularly in the east, as part of a broader pattern of violence and discrimination against women and girls. Soldiers and police, as well as Congolese and foreign armed groups, are among the main perpetrators. An increasing number of rapes by civilians are also reported. Many rapes, notably those committed by armed groups, involved genital mutilation or other extreme brutality. A number of armed groups also abduct women and girls as sex slaves. Few perpetrators of sexual violence have been brought to justice.

Using a sample of 900 survivors, research conducted in 2012 in the town of Goma and the territories of Masisi and Rutshuru in North Kivu province by the Centre for Research on Democracy and Development in Africa (CREDDA) and Heal Africa revealed the following findings: ${ }^{74}$

- $\quad$ Regarding trust in the Congolese courts and tribunals, 36,8 per cent of respondents said that a lack of trust in Congolese judges caused them not to bring offenders to justice; 26,5 per cent said that they did not have information on how to proceed; and 21 per cent said that they did not have the resources to bring cases to justice.

- $\quad$ Regarding the culture issue, 56,9 per cent of respondents said that it did not help women to report cases of rape to the courts; 42,4 per cent of respondents confirmed that local culture facilitates women to report cases of rape.

- $\quad$ Asked why the culture does not help women to report their assaults, 53,5 per cent of respondents said it was because they were afraid of being rejected by their husbands; 21,3 per cent said that it was due to fear of being stigmatised; and 11,7 per cent said that it was taboo.

- $\quad$ Concerning the alleged perpetrators, 30,9 per cent of respondents said that perpetrators were not afraid of the presence of NGOs, because rape continued and the number of victims increased; 13,1 per cent said that the state was weak, there was/is impunity and the judiciary was corrupt. Of the respondents, 12,1 per cent said that the alleged perpetrators were unknown.

- $\quad$ Regarding the persistence of rape, 42,8 per cent of respondents said that it continued regardless of the campaign against it. Of the respondents, 20,8 per cent said that it continued because the alleged perpetrators bribed authorities, and 12,2 per cent said that the alleged perpetrators remained free, which could not decrease the rates of rape.

- $\quad$ Concerning prosecutions, 74,8 per cent of respondents said that the alleged perpetrators were not prosecuted, but 23 per cent said the opposite. Giving reasons why perpetrators are not treated equally, 40,5 per cent of respondents said that it was because the military groups were untouchable and 31,9 per cent said that the military groups supported each other. Regarding the preference for resolving disputes outside the court, analysis found that 75,6 per cent of cases of sexual violence were resolved locally between the families of the victims and the perpetrators.

- $\quad$ Concerning the profile of perpetrators, 24,8 per cent of respondents said that the alleged perpetrators were foreign soldiers or combatants of armed groups, while 14,6 per cent said that they were military (wearing uniform); 8,6 per cent said that they were elements of the national police; 2,4 per cent said that they were agents of the

$74 \quad$ KK Bindu et al Etude d'impact du projet genre et justice/Heal Africa et d'identification des obstacles socioculturels qui bloquent l'accès à la justice des survivants des violences sexuelles: Etude réalisée conjointement par Heal Africa et CREDDA/ULPGL (2012) 61-66. 
National Intelligence Agency; 14 per cent said that they were civilians; 11 per cent said that perpetrators were either military (foreign and national, or rebels) or civilians, and 24,8 per cent said that they were unknown.

In the author's experience, ${ }^{75}$ there are different reasons why survivors do not feel that justice exists. Among them, the following may be highlighted:

There are no courts of law in the rural areas that have jurisdiction over crimes of sexual violence. The only tribunal that exists in those areas is the Tribunal de paix, which deals with crimes punishable by less than five years' imprisonment, while crimes of sexual violence are punishable from five to 20 years' imprisonment. If rape is committed by a civilian and the alleged perpetrator is found guilty, article $170(\mathrm{~d})$ of Law $06 / 018$ of 20 July 2006 provides that he or she will be punished by a 'criminal sentence of five to twenty years and a fine not ... less than 100000 Congolese francs'. In addition, article 7 bis (paragraph 4) of Law 06/019 of 20 July 2006 stipulates that the judicial police officer who receives a report of on offence related to sexual violence must notify the office of the public prosecutor to which he or she belongs within 24 hours. The issue is that the office of the prosecutor competent to deal with cases punishable by imprisonment of between five to 20 years is not in the rural areas, but only in towns such as Goma, Butembo and Beni in the case of North Kivu province. Moreover, only a limited number of officers are well trained; the judicial police in the rural areas are ill-equipped and they do not have the budget and means of transportation to conduct proper field investigations.

Taking the case of Masisi (around 80 kilometres from Goma), if the alleged perpetrator is arrested, there are often transportation problems for the judicial police in delivering the alleged perpetrators to the public prosecutor in Goma ${ }^{76}$ and complying with the law regarding the 24 hour time limit. Another problem for the survivors is travelling to and staying in Goma while the prosecutor reviews files sent by the judicial police officer. If there is enough evidence, the case must be submitted to the tribunal for judgment. Until judgment is given, the survivor is required to stay in Goma in order to attend hearings, to witness the sentencing if the perpetrator is found guilty, and also to witness the sentencing fines. Often, survivors are

75 Based on his field experience, but also on his previous research with local organisations, such the Centre for Research on Democracy and Development in Africa (CREDDA) and Heal Africa.

76 The North Kivu Province has six territoires (Beni rural, Lubero, Masisi, Nyiragongo, Rutshuru and Walikale) and three cities (Beni, Butembo and Goma). Goma is the capital city. In those cities, there are competent tribunals to deal with sexual violence in the towns, but not yet in all six territoires. Courts from Goma have jurisdiction to deal with crimes committed in Masisi, Nyiragongo, Rutshuru and Walikale; tribunals from Beni to deal with cases from the city of Beni and Beni rural; and tribunals from Butembo to deal with cases from the city of Butembo and Lubero. 
vulnerable and do not have sufficient means to pay for their accommodation or for a lawyer to assist them in the court of law.

The above situation has driven international partners to support state institutions by providing the judicial police with office supplies, training judicial police officers and magistrates, and providing motorcycles to improve their mobility for investigators ${ }^{77}$ in cases where rape and other forms of sexual violence occur. In addition, international partners financially support lawyers in assisting sexual violence survivors in courts of law. However, because the judicial police officers are not adequately remunerated, there is a risk that they will not do their job properly because of a lack of motivation. Consequently, considering the legal requirement to notify the public prosecutor of an incident within 24 hours, it can happen that investigations are not carried out properly and, therefore, because of a lack of sufficient evidence, the courts may acquit the accused. ${ }^{78}$ The disappointed survivor may claim that the judges were corrupt. Furthermore, there are situations where the perpetrator is wealthy and tries to negotiate an arrangement with the survivor's family. If the survivor's family is convinced beyond reasonable doubt that, with the medical report attesting that rape had been committed, and that the perpetrator will be sentenced, they may refuse the informal arrangement. When the perpetrator is acquitted, it is often alleged that he or she had corrupted the judges. Even where this is the case, it is very difficult to provide evidence of the alleged corruption. 79

Because there are no courts of law that have jurisdiction over rape and all forms of crimes of sexual violence in the rural areas, sometimes the government agrees to the support of international partners in organising mobile courts in areas where mass rape and other forms of sexual violence were perpetrated. ${ }^{80}$

On 20 November 2012, when the M23 rebel group occupied the town of Goma and its surroundings, it was reported that they had raped a number of women and girls, including 49 wives of FARDC soldiers, inside the military camp of Katindo. In addition, during their 'strategic retreats', Congolese soldiers are reported to have committed human rights violations, including rape, in Minova in the South Kivu province. $^{81}$ Following those allegations, on 5 May 2014 a mobile

77 The UN Mission in the DRC, the Restauration du Système Judiciaire au Congo (REJUSCO), the United Nations Development Programme (UNDP) and the American Bar Association (ABA) are among the partners involved.

78 On 28 June 2007, because of a lack of evidence, the military tribunal in Katanga acquitted five of the seven military personnel (see OHCHR (n 8 above) para 868). On 3 June 2004, because of a lack of evidence, the Bunia regional court acquitted Mathieu Ngudjolo because the prosecutor had no further evidence to support the accusations (see OHCHR (n 8 above) para 873).

79 See Bindu et al (n 74 above) 47-49.

80 See "Citing new report, UN urges DR Congo to end impunity for "widespread" sexual violence' (2014) http://www.un.org/apps/news/story.asp?NewsID=4753 4\#.VMizn8nsGDg (accessed 28 January 2015).

81 See UNJHRO (n 40 above) 8. 
operational military court was organised in Minova, where it convicted a lieutenant colonel and a corporal of rape in a mass rape trial of 39 soldiers. They were sentenced to life and 10 years' imprisonment respectively. ${ }^{82}$ Following the verdict, the SecretaryGeneral's special representative on sexual violence in conflict, Zainab Hawa Bangura, expressed her disappointment, saying that the sentence 'does not reflect the magnitude of the crimes of sexual violence that were committed and fails to do justice to all victims who had the courage to bring this case to court' ${ }^{83}$

In the Minova trial, it should be noted that the government had organised the mobile court after receiving international pressure to put an end to impunity for rape and other forms of sexual violence perpetrated by FARDC soldiers. ${ }^{84}$ Organising such a mobile court is a good thing in the process of fighting against impunity. However, under customary international law, the state has an obligation to investigate and prosecute grave human rights violations and to take action against those responsible. If the state fulfils its obligation there is no need for international pressure.

Violations of the right to physical integrity were committed in an environment where health facilities for appropriate medical and psychological care were almost non-existent. The mobile court was set up 18 months after these violations had been committed, and it was, therefore, very difficult for it to find beyond reasonable doubt that the alleged perpetrators were guilty. Furthermore, the international community did not wish to put pressure on Rwandan 85 and Ugandan governments that still hosted rebels alleged to have committed rape and other forms of sexual violence, either to prosecute or to extradite them.

82 A Kambale 'Two DR Congo soldiers convicted of rape in mass trial' (2014) http:// reliefweb.int/report/democratic-republic-congo/only-three-dr-congo-soldiers-con victed-rape-mass-trial (accessed 28 January 2015).

83 See 'DR Congo mass rape verdict fails to deliver justice to victims, says UN envoy' (n 80 above).

84 On 9 April 2014, UN officials called on the government of the DRC to step up the fight against impunity for rape and sexual violence, which remain widespread and largely unpunished despite some progress in holding perpetrators accountable. Navi Pillay, then the UN High Commissioner for Human Rights, 'called on the government to prioritise the fight against impunity for crimes of sexual violence, to promptly complete effective and independent investigations, and to prosecute alleged perpetrators, including those suspected of having command responsibility'. See 'Citing new report, UN urges DR Congo to end impunity for "widespread" sexual violence' (n 80 above).

85 At the time of writing, there has been no international pressure requesting either to investigate and prosecute or extradite alleged perpetrators who fled in Rwanda and Uganda. However, some international pressure against both countries was exerted in order to stop any kind of support to M23 committing serious crimes. Eg, for its support to the M23 rebel group, the United States has moved to halt its military aid to Rwanda because the rebel group was recruiting, abducting and using child soldiers to participate actively in hostilities during the armed conflict in the neighbouring DRC. See A Ahmed 'US sanctions Rwanda, others over child soldiers' http://america.aljazeera.com/articles/2013/10/4/u-s-sanctions-rwanda othersoverchildsoldiers.html (accessed 7 September 2015). 


\section{Way forward and concluding remarks}

Cases of CRSV are innumerable in the eastern DRC despite numerous initiatives to fight these heinous and serious crimes, and despite the adoption of two laws against sexual violence on 20 July 2006. Perpetrated in armed conflict situations, rape and others form of sexual violence are strongly prohibited and criminalised by the core bodies of international humanitarian law that have been ratified universally and that bind all concerned parties, including non-state actors. In order to hold perpetrators criminally responsible for rape and other crimes of sexual violence, the right to justice is well protected by a number of international instruments. However, survivors face many challenges in accessing justice. Among these are cultural norms, stigmatisation, fear of reprisal and rejection. The judiciary faces other challenges, including insufficient funds, poor representation in rural areas, poor equipment and a lack of education on crimes of sexual violence.

To improve this situation, it is argued that it is urgent that the Congolese government establish competent courts of law to deal with crimes of sexual violence in rural areas and to ensure that officers of the judicial police are well trained and well remunerated. The judicial police must be well equipped with means to conduct investigations rapidly and gather the elements of proof in order to bring the alleged perpetrators before the competent authorities in a timely manner and thus to comply with the law. Survivors should be well prepared, well informed and encouraged by psychologists to see that breaking the silence is an effective way of eradicating rape and other forms of sexual violence. Local communities should also be sensitised so that they do not reject survivors because they have been abused.

The Congolese army has a duty to train all integrated rebels in international humanitarian law and to ensure that they are sufficiently educated and have mastered the humane conduct of armed conflict before they are deployed on the battlefield. In this regard, in his report of March 2015, the UN Secretary-General ${ }^{86}$

urge[d] the government of the Democratic Republic of the Congo to ensure full implementation of the armed forces action plan against sexual violence, to systematically bring perpetrators to justice and to deliver reparations to victims, including payment of outstanding compensation awards.

Realistically, it must be admitted that the large scale of rape and other forms of sexual violence perpetrated against women and girls in the North Kivu province is almost certainly linked to armed conflict and

86 UNSC (n 12 above) para 27. 
insecurity. ${ }^{87}$ Thus, it is urgent for the government to put an end to insecurity and to all armed groups and thereby to restore state authority. For the warlords who fled to neighbouring countries and are alleged to have perpetrated mass rape and other forms of sexual violence, it is the duty of the government to keep insisting that those countries either prosecute them or arrest and extradite them to the DRC, or to a neutral country exercising universal jurisdiction, or to the ICC, as these crimes were committed in the territory of a state party to the Rome Statute.

$87 \mathrm{Eg}$, Brown finds that 'the insecurity that rapidly took hold in all areas of the province has led to acts of violence - pillaging, killing, rape, setting fire to houses indiscriminately perpetrated by members of the various armed groups involved in the conflict'. See C Brown 'Rape as a weapon of war in the Democratic Republic of the Congo' (2011) 15 http://digitalcommons.calpoly.edu/cgi/viewcontent.cgi? article $=1046 \&$ context $=$ socssp $($ accessed 11 November 2015). 